\title{
Evaluation of Potential Releases from Single-Shell Tanks
}

J. V. Ramsdell, Jr.

March 1992

Prepared for the U.S. Department of Energy under Contract DE-AC06-76RLO 1830

Pacific Northwest Laboratory Operated for the U.S. Department of Energy by Battelle Memorial Institute 


\title{
DISCLAIMER
}

This report was prepared as an account of work sponsored by an agency of the United States Government. Neither the United States Government nor any agency thereof, nor Battelle Memorial Institute, nor any of their employees, makes any warranty, expressed or implied, or assumes any legal liability or responsibility for the accuracy, completeness, or usefulness of any information, apparatus, product, or process disclosed, or represents that its use would not infringe privately owned rights. Reference herein to any specific commercial product, process, or service by trade name, trademark, manufacturer, or otherwise does not necessarily constitute or imply its endorsement, recommendation, or favoring by the United States Government or any agency thereof, or Battelle Memorial Institute. The views and opinions of authors expressed herein do not necessarily state or reflect those of the United States Government or any agency thereof.

\author{
PACIFIC NORTHWEST LABORATORY \\ operated by \\ BATTELLE MEMORIAL INSTITUTE \\ for the \\ UNITED STATES DEPARTMENT OF ENERGY \\ under Contract DE-AC06-76RLO 1830
}

Printed in the United States of America

Available to DOE and DOF contractors from the

Office of Scientific and Technicil Information, P.O. Box 62, Oak Ridge, TN 37831; prices available from (615) 576-8401. FTS 626-8401.

Available to the public from the National Technical Information Service, U.S. Department of Commerce, 5285 Port Royal Rd., Springfield, VA 22161. 
PNL --8029

DE92 011508

PNL-8029

UC -602

EVALUATION OF POTENTIAL RELEASES

FROM SINGLE-SHELL TANKS

J.V. Ramsde11, Jr.

March 1992

Prepared for

the U.S. Department of Energy

under Contract DE-AC06-76RI.0 1830

Pacific Northwest Laboratory

Richland, Washington 99352 


\section{SUMMARY}

Potential toxic chemical concentrations in the air near vents of singleshel1 tanks have been evaluated using three scenarios. The first scenario duplicates the conditions existing the morning of January 28, 1992, when several workers reported exposure to toxic or irritating gases near the $B X$ and BY tank farms in the 200-East Area at Hanford. The results of this scenario indicate that it is unlikely that a tank in either tank farm could have been the source of the gases associated with the incident. In the other two scenarios, maximum potential concentrations under worst-case and bounding conditions were examined. The results of these scenarios show that air concentrations of all toxic gases reported to be in the tanks fall below their time-weighted average, threshold limiting values within $5 \mathrm{~m}$ of tank vents under worst-case conditions involving a restricted air flow to the tanks. When unrestricted air flow to the tanks and worst-case conditions are assumed, the maximum gas concentrations fall below time-weighted average, threshold limiting values within $15 \mathrm{~m}$ of vents. 


\section{CONTENTS}

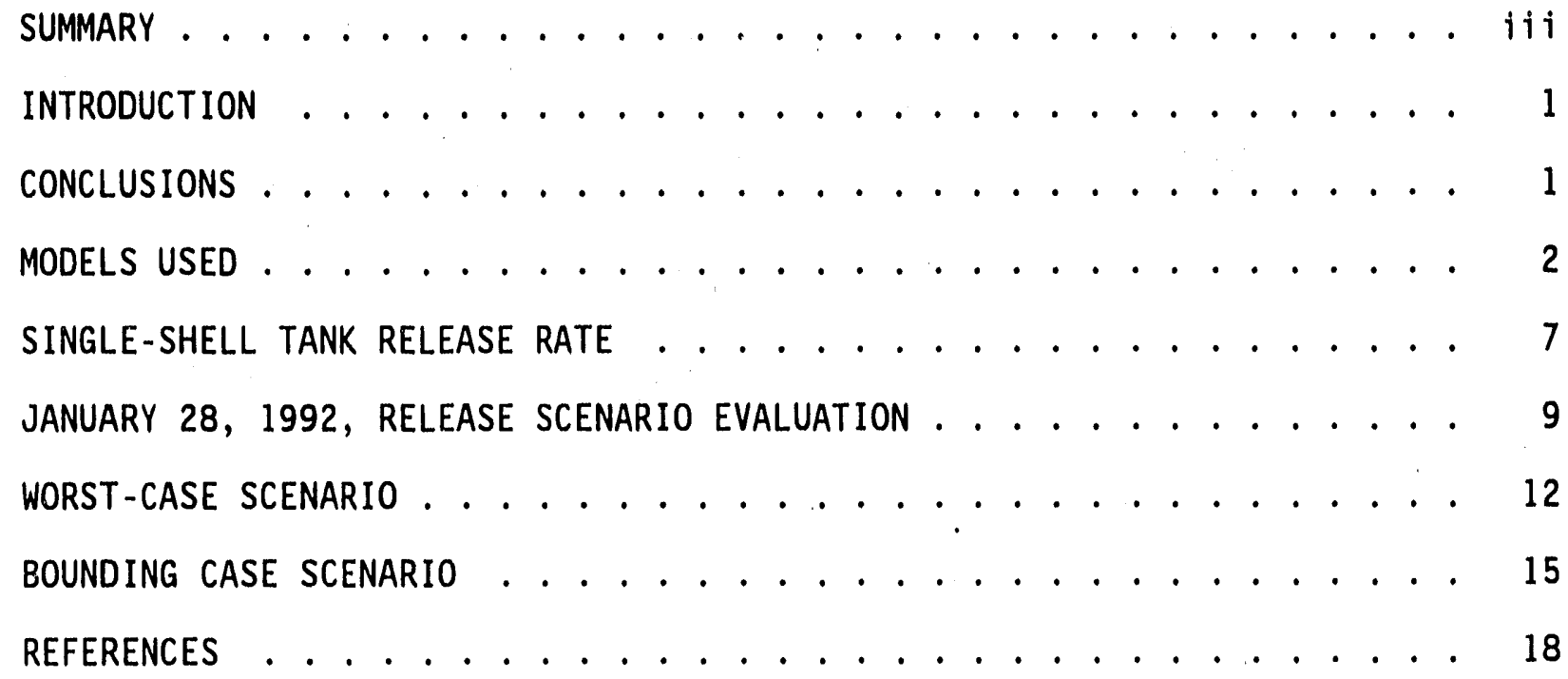




\section{INTRODUCTION}

On January 28, 1992, several workers at a dri11 site adjacent to BX and BY tank farms in the 200-East Area at Hanford reported exposure to toxic or irritating gases. The $B X$ and $B Y$ tank farms are a potential source for these gases. Therefore, the Pacific Northwest Laboratory (PNL) was asked to estimate concentrations that might be expected from releases from the tanks. Specifically, the two questions addressed to PNL were:

1) What might the concentrations have been from tank releases in the $B Y$ and BX tank farms the morning of January 28, 1992?

2) What are the maximum concentrations that might be expected from tanks in the BY, BX, and C tank farms?

This report is PNL's response to those questions. The report contains a description of the mathematical models used to estimate the concentrations, lists the assumptions made in the calculations, and presents the results of the evaluation.

\section{CONCLUSIONS}

Three single-shell tank release scenarios were examined in detail. Each scenario involves assumptions designed to ensure that model concentration predictions do not underestimate actual concentrations. The first two scenarios are routine releases in the sense that they could occur under normal operations. The third scenario assumes that a large opening is available to supply air to the tanks.

The first scenario is based on conditions existing on the morning of January 28, 1992. The wind direction a' the time of the incident makes it unlikely that a release from either BY or BY tank farm would have affected the drill site where the personnel exposures took place. Further, dispersion modeling results indicate that the maximum concentration of each of the known gases in the tanks would be less than $1 \%$ of its time-weighted average, threshold limit value (TLV) at a distance equivalent to the distance between the tank farms and the drill site. Therefore, it is unlikely that a tank in either tank farm was the source of the gases associated with the incident. 
The second scenario evaluated the concentrations that might occur under a postulated set of worst-case conditions not involving physical modification of the openings to the tanks. In this scenario, the gas concentrations fall below TLVs within $5 \mathrm{~m}(16 \mathrm{ft})$ of the tank vent. The concentrations would be less than $20 \%$ of the TLV by $10 \mathrm{~m}(31 \mathrm{ft}$ ), and less than $1 \%$ of the TLV by $50 \mathrm{~m}$ (165 ft).

The third scenario is a bounding case. The scenario includes the worst case scenario conditions. In addition, the restrictions on flow into the tanks are removed because a $42 \mathrm{in}$. access cover is assumed to be open. In this case, the concentrations well above TLVs are possible near the tank vents. However, concentrations decrease to the TLV at about $12 \mathrm{~m}(40 \mathrm{ft})$ and fall to less than $2 \%$ of the TLV by $100 \mathrm{~m}(310 \mathrm{ft})$.

\section{MODELS USED}

The primary model used to evaluate the potential releases from the single-shell tanks is the straight-line Gaussian dispersion model for concentrations at the plume centerline during a continuous uniform release. The model is

$$
x / Q^{\prime}=\left(F^{\prime}+\pi U \sigma_{y} \sigma_{z}\right)^{-1}
$$

where $x=$ the concentration at ground level on the axis of the plume $\left(\mathrm{mg} / \mathrm{m}^{3}\right)$

$Q^{\prime}=$ the release rate $(\mathrm{mg} / \mathrm{s})$

$F^{\prime}=$ the flow rate of the source $\left(\mathrm{m}^{3} / \mathrm{s}\right)$

$U=$ the wind speed $(\mathrm{m} / \mathrm{s})$

$\sigma_{y}=$ the horizontal diffusion coefricient (m)

$\sigma_{z}=$ the vertical diffusion coefficient $(m)$.

Equation (1) assumes complete reflection of material at the ground (no deposition) and no depletion from chemical or physical transformation of the effluent. It is appropriate for estimating $30-\mathrm{min}$ to $1-\mathrm{hr}$ average concentrations downwind of a continuous release at ground level.

Release rates for single-shell tanks have not been measured directly. They have been estimated from concentrations reported for the headspaces in 
the 102-C and 103-C tanks ${ }^{(a)}$ and preliminary concentration estimates for tank $B Y-104^{(b)}$ and the flow rate through the tank air vents. Vent flow rates have been estimated by $C l a y b r o o k^{(c)}$ for a variety of scenarios including the atmospheric conditions on the morning of January 28, 1992. Given the concentration and flow, the release rate is calculated from

$$
Q^{\prime}=x_{t} F^{\prime}
$$

where $x_{t}$ is the concentration in the tank $\left(\mathrm{mg} / \mathrm{m}^{3}\right)$, and $F^{\prime}$ is the vent flow $\left(\mathrm{m}^{3} / \mathrm{s}\right)$.

Wind speeds selected for use in Equation (1) range from $1.5 \mathrm{~m} / \mathrm{s}$ to $6 \mathrm{~m} / \mathrm{s}$. A wind speed of $1.5 \mathrm{~m} / \mathrm{s}$ is near the low end of the wind speed range for which Equation (1) is valid. At lower wind speeds, the model gives unrealistically high concentrations. The U.S. Nuclear Regulatory Commission (NRC 1982) permits reduction of concentrations estimated by Equation (1) whenever the wind speed is less than $6 \mathrm{~m} / \mathrm{s}$ in neutral and stable atmospheric conditions. The wind speed at the time of the January 28, 1992 event was about $6 \mathrm{~m} / \mathrm{s}$. Using a wind speed greater than $6 \mathrm{~m} / \mathrm{s}$ would not result in concentration estimates that are higher than those obtained with a $6-\mathrm{m} / \mathrm{s}$ wind speed.

The diffusion coefficients $\left(\sigma_{y}\right.$ and $\sigma_{z}$ ) are measures of the spread of the plume. They are generally considered to be functions of atmospheric stability and distance from the release point. Frequently, they are estimated using graphs that contain curves relating diffusion coefficient to distance and stability (e.g., Gifford 1961). However in this instance, the distances

(a) Ulbricht, W. H., Jr. 1991. "Report on the 241-C Tank Farm Air Sampling Results of 1989." WHC-SD-WM-RPT-019 Rev. 0, Westinghouse Hanford Company, Richland, Washington. Hereinafter referred to as Ulbricht 1991.

(b) Pinge1, L. 1992. "Preliminary Results of BY-104 Vapor Space Monitoring." Memo dated January 28, 1992, to G. T. Dukelow, Westinghouse Hanford Company. Hereinafter referred to as Pingel 1992.

(c) Claybrook, S. W. 1992. "Natural Circulation Rate Predictions for the Tank BY-104." Memo dated February 12, 1992 to R. E. Raymond, Westinghouse Hanford Company. Hereinafter referred to as Claybrook 1992. 
involved are generally less than the lower limits of the graphs. Rather than extrapolate the curves, the diffusion coefficients are estimated as a function of trave time and stability using atmospheric boundary layer similarity theory. This approach is widely recommended where atmospheric turbulence measurements are available (Gifford 1976; Gryr.ing 1987; Hanna et a1. 1977; Irwin 1983; Randerson 1979; Weil 1985).

In this approach, the horizontal diffusion coefficient is calculated using

$$
\sigma_{y}=\sigma_{v} t F_{y}(t)
$$

where $\sigma_{v}$ is the standard deviation of the crosswind component of the wind vector $(\mathrm{m} / \mathrm{s}), t$ is the time since release $(\mathrm{s})$, and $F(t)$ is a nondimensional factor related to the turbulence time scale. A similar expression is used to estimate the vertical diffusion coefficient. In that expression, $\sigma_{w}$, the standard deviation of the vertical component of the wind vector replaces $\sigma_{v}$, and $F_{z}(t)$ replaces $F_{y}(t)$. In the present application, both $F_{y}(t)$ and $F_{z}(t)$ may be assumed to have a value of 1.0 in calculation of the diffusion coefficients used in Equation (1). The full expressions for $F_{y}(t)$ and $F_{z}(t)$ will be used in computing diffusion coefficients used to estimate concentrations during calm wind conditions.

Turbulence measurements are not made routinely as part of the observations at the Hanford Meteorological Station. However, $\sigma_{v}$ and $\sigma_{w}$ can be predicted from the friction velocity, $u_{*}$, which is a scaling velocity for wind profiles and turbulence statistics in the atmosphere (Hanna, Briggs, and Hosker 1982; Panofsky and Dutton 1984). Furthermore, the friction velocity can be estimated directly from a wind measured at a known height if the stability and surface roughness length, $z_{0}$, are known. The surface roughness length in the vicinity of the 200 Areas at Hanford has been estimated in many of the meteorological research programs conducted by PNL and predecessor contractors. Typical estimates range from about 0.03 to $0.1 \mathrm{~m}$ (Horst and Elderkin 1970; Powell 1974).

Consequently, the following relationships are used to estimate $\sigma_{v}$ and $\sigma_{w}$. The logarithmic wind profile, which describes the variation of wind speed with height in the atmospheric boundary layer in neutral conditions is 


$$
U(z)=u_{*} / k \ln \left(z_{1} / z_{0}\right)
$$

where $z$ is the height above ground $(m)$ and $k$ is the dimensionless von Karman constant with a value of about 0.4 . A wind measurement height of about $10 \mathrm{~m}$ and a surface roughness of $0.05 \mathrm{~m}$ are appropriate for Hanford. Making these substitutions, the friction velocity is estimated as

$$
u_{*}=0.0755 U \text {. }
$$

Hanna, Briggs, and Hosker (1982) suggest that within a few meters of the ground during stable and neutral atmospheric conditions, $\sigma_{v}$ and $\sigma_{w}$ are approximately equal and are related to $u_{*}$ by

$$
\sigma_{v}=\sigma_{w}=1.3 u_{*} .
$$

These equations give a narrow, conical plume that has $\sigma_{y}$ and $\sigma_{z}$ values of about $1 \mathrm{~m}$ at a distance of $10 \mathrm{~m}$ from the release point.

Equations (1) through (6) are suitable for estimating concentrations for wind speed that are not too close to 0 . As a practical matter, the wind speed is defined as calm when the wind speed is below the threshold of an anemometer. During these conditions, there are still air motions that disperse material. Gaussian puff models can be used to evaluate potential concentrations during "calm" winds.

The Gaussian puff model for an instantaneous ground-level release is

$$
\chi(r, t) / Q=2 G(r, t) /\left[(2 \pi)^{3 / 2} \sigma_{r}^{2}(t) \sigma_{z}(t)\right]^{-1}
$$

where $t$ is the time following release, $Q$ is the mass of material released, $r$ is the distance from the center of the puff, and $\sigma_{r}$ is the radial diffusion coefficient. The $G(r)$ term is an exponential expression that specifies the variation in concentration as a function of distance from the puff center. It has the form

$$
G(r, t)=\exp \left\{-0.5\left[r / \sigma_{r}(t)^{2}\right]\right\}
$$


The diffusion coefficients in Equations (7) and (8) must be specified as a function of time following release rather than distance from the source. Having shown the dependencies of $\chi, G, \sigma_{r}$, and $\sigma_{z}$ on $r$ and $t$ explicitly, we will dispense with this formality for the remainder of the discussion.

Equations (7) and (8) cannot be used directly to estimate concentrations that might result from a continuous release in calm winds. However, a continuous release in calm conditions can be modeled by a sequence of puffs. For a constant release rate, we rewrite Equation (7) as

$$
x / Q^{\prime}=\sum_{t=0}^{N \Delta t}\left\{2 G \Delta t /\left[(2 \pi)^{3 / 2} \sigma_{r}^{2} \sigma_{z}\right]^{-1}\right\}
$$

where $Q^{\prime}$ is the reledse rate, $\Delta t$ is the time interval (s) between puffs, and $N$ is the number of puffs released since the start of the release. Note that $t=$ $n \Delta t$ for $0 \leq n \leq N$.

The diffusion coefficients in Equation (9) are each proportional to time to a power greater than $1 / 2$. Equation (9) is of the general form

$$
x / Q^{\prime} \propto \sum n^{-v}
$$

with $v>1$. Therefore, the summation converges to a limit for $\mathrm{N}$ sufficiently large and sufficiently small $\Delta t$. In both cases, sufficiency is a function of distance and the velocity selected to characterize the random air motions.

Having arrived at Equation (9) and determining that the equation has an asymptotic limiting value, we turn to estimation of the diffusion coefficients. For consistency with the plume model, we would like to use Equations (3) and (6) to estimate diffusion coefficients for Equation (9). To do this, we must relate the diffusion coefficients to something other than the mean wind speed, and we must supply initial values of the diffusion coefficients for $t=0$. The first of these objectives is accomplished by setting the friction velocity, $u_{*}$, to a suitably small value. A value of $0.05 \mathrm{~m} / \mathrm{s}$ has been assumed for this purpose. The second objective is accomplished by setting the concentration at the center of each puff equal to the concentration at the release point 


$$
x / Q^{\prime}=1 / F^{\prime}=2 \Delta t /\left[(2 \pi)^{3 / 2} \sigma_{r o}^{2} \sigma_{z 0}\right]
$$

If we now assume that $\sigma_{\text {ro }}=\sigma_{z 0}=\sigma_{0}$, then

$$
\sigma_{0}=2 F^{\prime} \Delta t /(2 \pi)^{3 / 2} \text {. }
$$

A short computer code that implements the model described by Equations (7) through (12) has been developed. Tests of the code show that with the assumption of $u_{*}=0.05 \mathrm{~m} / \mathrm{s}, x / Q^{\prime}$ has reached or is approaching a 1 imiting value at distances of $100 \mathrm{~m}$ or less when $\mathrm{N}=120$ and $\Delta t=30 \mathrm{~s}(t=1 \mathrm{hr})$. A cursory examination of the sensitivity of the limiting value to $\Delta t$ shows that $\Delta=30 \mathrm{~s}$ is reasonable but leads to small overestimates of the limiting value. Estimates of the limiting concentration are sensitive to changes in the value of $u_{*}$. Increasing $u_{*}$ to $0.1 \mathrm{~m} / \mathrm{s}$ reduces the 1 imiting $x / Q^{\prime}$ by a factor of about 2.2 and decreases the time required to reach the 1 imiting value. Decreasing the value of $u_{*}$ to $0.025 \mathrm{~m} / \mathrm{s}$ has opposite effects. Hanna and Chang (1992) suggest that $\sigma_{v}$ near the ground has a minimum value of about $0.5 \mathrm{~m} / \mathrm{s}$. Assuming $u_{*}=0.05 \mathrm{~m} / \mathrm{s}$ results in a $\sigma_{v}=0.065 \mathrm{~m} / \mathrm{s}$, which is clearly conservative when compared with $0.5 \mathrm{~m} / \mathrm{s}$.

\section{SINGLE-SHELL TANK RELEASE RATE}

Equation (2) equates the release rate to concentration and flow. For the analyses described below, the concentration used to estimate the singleshell tank release rate was selected from Table 3 of Ulbricht's report ${ }^{(a)}$. That table 1 ists concentrations for organic gases measured in the headspaces of tanks 102-C and 103-C after the tanks had been sealed for several months. Table 1 lists the maximum concentration reported for each gas, regardless of tank or measurement location. Preliminary measurements ${ }^{(b)}$ indicate that organic gas concentrations measured in tank BY-104 are significantly lower than those listed in Table 1 for the same gases. For example, the concentration of 1-butanol was a factor of 80 lower in tank BY-104, and the

(a) Ulbricht 1991.
(b) Pingel 1992. 
Table 1. Maximum Organic Gas Concentrations $\left(\mathrm{mg} / \mathrm{m}^{3}\right)$, Measured in Tanks 102-C and 103- $c$ in October $1989^{(a)}$

\begin{tabular}{|c|c|c|c|c|c|}
\hline Material & Tank Conc. & TLV & STEL & CEILING & $\%$ TLV \\
\hline $\begin{array}{l}\text { 1-butanol } \\
\text { methylene chlor'ide } \\
\text { acetone } \\
\text { carbon disulfide } \\
\text { chloroform } \\
\text { trichlorofluoromethane } \\
1,1,1 \text {-trichroroethane } \\
\text { carbon tetrachloride } \\
1,3 \text {-dichloropropene } \\
\text { benzene } \\
\text { vinyl acetate } \\
2 \text {-butanone } \\
2 \text {-hexanone } \\
\text { tetrachloroethylene } \\
\text { toluene } \\
4 \text {-methyl-2-pentanone } \\
1,1,2,2-\text { tetrachloroeth. } \\
\text { o-xylene } \\
\text { tributyl phosphate } \\
n \text {-paraffin hydrocarbons } \\
\text { ammonia }\end{array}$ & $\begin{array}{l}3.72 E+02 \\
2.50 E+00 \\
2.16 E+03 \\
6.80 E-02 \\
2.70 E-02 \\
4.80 E-01 \\
2.71 E-01 \\
5.00 E-02 \\
2.40 E-02 \\
2.80 E-01 \\
6.80 E-01 \\
2.58 E+01 \\
5.70 E+00 \\
5.20 E-02 \\
6.20 E+01 \\
1.40 E+00 \\
2.69 E-02 \\
3.10 E+00 \\
1.97 E+02 \\
1.10 E+04 \\
2.60 E+02\end{array}$ & $\begin{array}{l}1.7 \mathrm{E}+02 \\
1.8 \mathrm{E}+03 \\
3.1 \mathrm{E}+01 \\
4.9 \mathrm{E}+01 \\
1.9 \mathrm{E}+03 \\
3.1 \mathrm{E}+01 \\
4.5 \mathrm{E}+00 \\
3.2 \mathrm{E}+01 \\
3.5 \mathrm{E}+01 \\
5.9 \mathrm{E}+02 \\
2.0 \mathrm{E}+01 \\
3.4 \mathrm{E}+02 \\
3.8 \mathrm{E}+02 \\
2.1 \mathrm{E}+02 \\
6.9 \mathrm{E}+00 \\
4.3 \mathrm{E}+02 \\
2.2 \mathrm{E}+00 \\
1.8 \mathrm{E}+02 \\
1.7 \mathrm{E}+01\end{array}$ & $\begin{array}{l}7.0 E+01 \\
8.9 E+02 \\
1.4 E+03 \\
5.7 E+02 \\
3.1 E+02 \\
6.5 E+02\end{array}$ & 5. $6 \mathrm{E}+03$ & $\begin{array}{r}1.40 \\
120.00 \\
0.22 \\
0.06 \\
\\
0.01 \\
0.16 \\
0.53 \\
0.88 \\
1.90 \\
4.4 \\
29.00 \\
0.02 \\
16.00 \\
0.68 \\
0.39 \\
0.71 \\
9000.00 \\
6300.00 \\
1500.00\end{array}$ \\
\hline
\end{tabular}

concentration of acetone was a factor of 250 lower. Therefore, the concentration used in estimating the release rate for single-shell tanks is based on measurements of the concentrations in the headspace of tanks 102-C and 103-C.

Table 1 also lists exposure limits set for each of the gases in milligrams per cubic meter. The column headed TLV gives the Threshold Limit Value for occupational exposure to the gas (ACGIH 1990). This is the maximum timeweighted average concentration to which workers can exposed on a routine basis ( $8 \mathrm{hr} /$ day, 5 days/week). Note that a TLV does not exist for an unspecified mixture of $n$-paraffin hydrocarbons; the TLV 1 isted is for $n$-hexane. The TLV for $n$-hexane was chosen ever though $n$-hexane is not on the 1 ist of compounds included in $n$-paraffin hydrocarbons because $n$-hexane is chemically similar to other compounds on the $n$-paraffin hydrocarbon list and has a lower timeweighted average TLV (50 ppm) than other compounds on the list. The compound

(a) UTbricht 1991. 
with the next lowest TLV is nonane $(200 \mathrm{ppm})$. The columns labeled STEL and Ceiling give concentration limits for shorter exposure periods. The final column in Table 1 gives the ratio of maximum headspace concentration to the TLV in percent. Those gases with ratios greater than $100 \%$ are of concern, and tributyl phosphate is of most concern. Therefore, the following analys is is based on a release of tributyl phosphate and assumes a tank headspace concentration of $197 \mathrm{mg} / \mathrm{m}^{3}$.

Flow rates for the analysis, obtained from S. Claybrook ${ }^{(a)}$, are based on a finite-difference model of the tank system. For the January 28, 1992, scenario, the tank system consisted of an isolated tank, and for the worstcase scenarios, the tank system comprised two tanks joined in series by a 3-in. overflow pipe. Each tank has access openings and a vent. The flow rate through the release vent depends, to a large extent, on the atmospheric pressure tendency, the temperature differences among the tanks and between the tanks and the atmosphere, and the infiltration of air from the atmosphere to the tanks. The tank circulation model does not consider the effects of wind speed on vent flow. However, these effects should be small because the vent outlets are generally within a foot or two of the ground and are pointed directly toward the ground.

\section{JANUARY 28, 1992, RELEASE SCENARIO EVALUATION}

The event that triggered this analysis was exposure of personnel to irritating and possibly toxic fumes at a drill site near the BY and BX tank farms between $8: 30 \mathrm{a} . \mathrm{m}$. and 9:30 a.m. on the January 28, 1992. The locations on the drill site where the fumes were reported were generally north of the tank farms and 200 to 300 feet from the closest tanks.

Records of the Hanford Meteorology Station, located about 3 miles to the west of the event site, and of the 200-East Area telemetry station, located about a mile southeast of the event site, show southerly winds at about $10 \mathrm{mph}$ at the beginning of the period. During the period, the wind directions varied from southerly to southwesterly and the wind speed freshened. By the end of the period, the winds were southwesterly at greater than $20 \mathrm{mph}$. The records

(a) Claybrook 1992. 
also show that the station barometric pressure was rising continuously throughout the period and that the ambient air temperature was about $54^{\circ} \mathrm{F}$.

Based on a 0.02-in. Hg per hour pressure increase, which is less than observed, and an ambient air temperature of $54^{\circ} \mathrm{F}, \mathrm{Cl}_{\text {aybrook estimates }}{ }^{(a)}$ a flow of $2.6 \mathrm{cfm}\left(0.0012 \mathrm{~m}^{3} / \mathrm{s}\right)$ through a 4 -in. vent for an isolated tank at. a temperature of $80 \circ \mathrm{F}$. The release rate corresporiting to this flow and a tributyl phosphate concentration of $197 \mathrm{mg} / \mathrm{m}^{3}$ in the tank headspace is $0.24 \mathrm{mg} / \mathrm{s}$.

Figure 1 shows plume centerline [Equation (1)] concentrations of tributyl phosphate as a percentage of the TLV versus distance for a $0.24 \mathrm{mg} / \mathrm{s}$ release rate and the meteorological conditions of the morning of January $28 t h$. The predicted concentrations are an order of magnitude lower than the TLV at a distance of $10 \mathrm{ft}(3 \mathrm{~m})$ from the vent. At a distance of $165 \mathrm{ft}(50 \mathrm{~m})$, the model predicts that the concentrations will be well be? ow $0.1 \%$ of the TLV.

It is likely that the concentrations predicted in Figure 1 exceed the actual concentrations in the plume at the time of the event because

1) The tank headspace concentration and vent flow are used to estimate the release rate for the model calculation to give the maximum potential release rate. If the concentrations in the BY104 tank are typical of concentrations in the tanks in the $B Y$ and $B X$ tank farms, the concentrations in Figure 1 may be high by a factor of 100 .

2) The model used does not account for any dispersion caused by structures, changes in topography, or the impaction of the air flow from the vent on the ground beneath the vent. These omissions will cause the model to overestimate concentrations near the release point. As the distance from the tank increase, these omissions become insignificant.

3) The dispersion model does not account for plume meander. Wind records from the 200-East Area telemetry station show that the 15-min wind direction averages between 0830 and 0930 on January 28, 1992, ranged from $190^{\circ}$ to $240^{\circ}$. This meander would reduce the average concentration at any location downwind of the tank farms.

4) The concentration in the tank headspace and the forces driving the release are assumed to be unaffected by dilution from the infiltrating air.

(a) Claybrook 1992. 


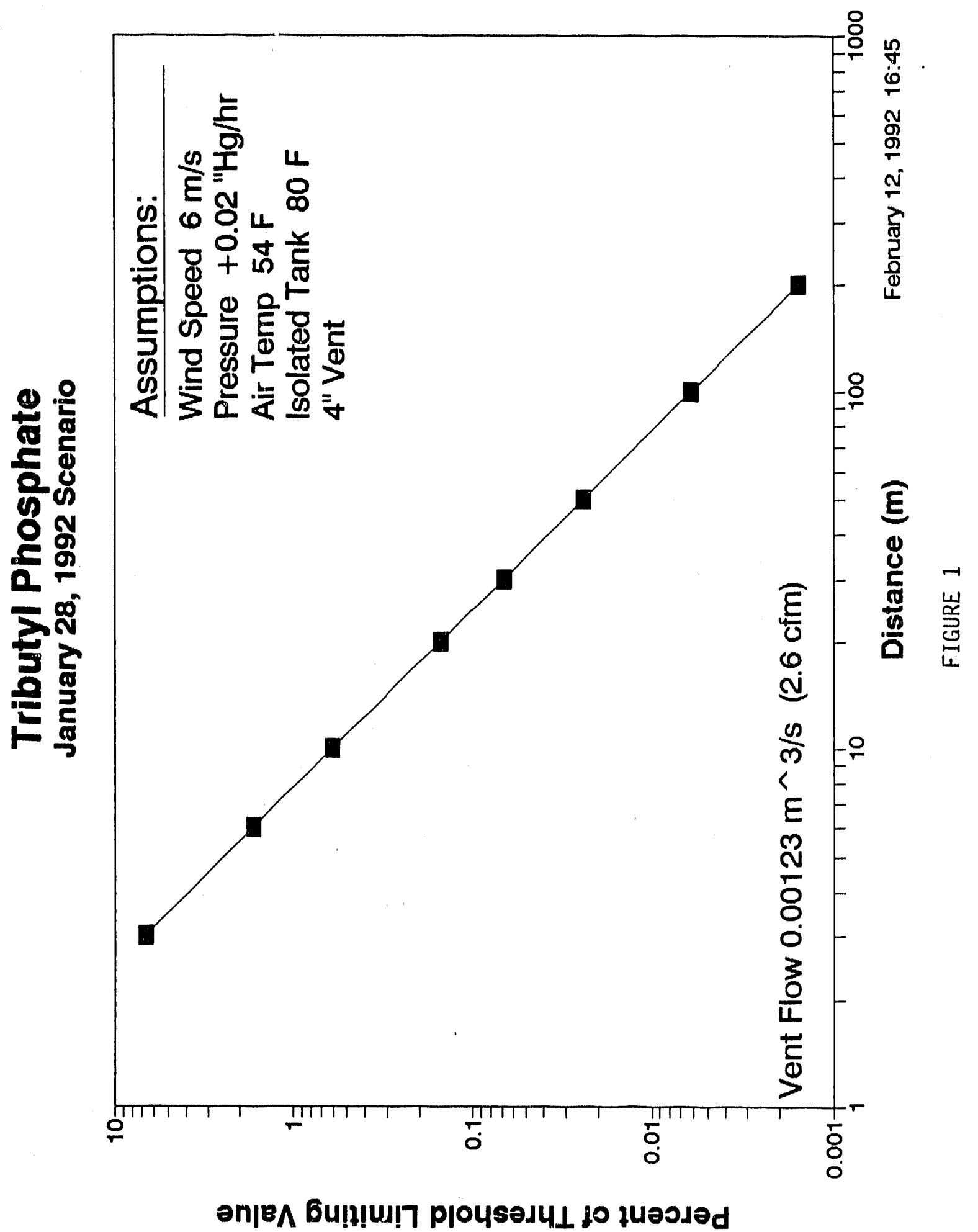


There is a possibility that short-term concentrations could exceed the predicted concentrations. Gaussian plume dispersion models [e.g., Equation (1)] estimate concentrations averaged over periods on the order of $30 \mathrm{~min}$ to $1 \mathrm{hr}$. Within this period, concentrations fluctuate above and below the average. Concentration fluctuation data collected in experiments at Hanford (Ramsdell and Hinds 1971) indicate that 1-min average concentrations near the centerline of a ground-level plume exceed the 30 -min average by a factor of 4 or more about $1 \%$ of the time.

Given the low concentrations predicted by the model, and the likelihood that the model predictions are high, it is unlikely that the January 28, 1992, exposure event was caused by a release from either the BX or the BY tank farm. If the actual time of exposure was later than 0900, the probability of a release from either of these tank farms being the cause of the exposure is extremely low because the wind following 0900 was from the southwest and steady. Any gas released after 0900 would have passed well to the east of the locations where the exposure occurred.

\section{WORST-CASE SCENARIO}

A second scenario was examined to evaluate the maximum potential hazard associated with releases from tank vents. This scenario was selected to maximize the vent flow and minimize atmospheric dispersion. The atmospheric conditions for the scenario were a low ambient air temperature, rapidiy falling pressure, a low wind speed, and stable atmospheric conditions. The low wind speed and stable atmosphere minimize atmospheric dispersion and are consistent with atmospheric conditions generally used in safety evaluations. The low temperature and falling pressure are included in the scenario to maximize the driving force for the release. The tank system for the scenario included two tanks to increase the inflow to the tank from which the release is occurring, a larger vent, and an elevated tank temperature. In this scenario, as in the previous scenario, the tank headspace concentration of tributyl phosphate given in Table 1 is used to estimate the release rate.

It should be noted that the releases in the worst-case and January 28 , 1992, scenarios are "normal" events driven by environmental conditions. In neither case is the release caused by an accident or rare event such as an 
earthquake or tornado. However, the specific combination of conditions assumed in the worst-case scenario is extremely unlikely (probably $<0.01 \%$ ).

In the worst-case scenario, the ambient air temperature is assumed to be $29 \circ \mathrm{F}$. This is approximately average air temperature during January, which is the coldest month at Hanford (Stone et al. 1983). The barometric pressure is assumed to be falling at 0.16 inches $\mathrm{Hg} / \mathrm{hr}$. This rate of pressure decrease was observed as a frontal system approached Hanford November 3, 1958 (Stone et a1. 1983). However, in the last 10 years, pressure falls exceeding $0.10 \mathrm{in.} / \mathrm{hr}$ have occurred at the Haliford Meteorology Station only 16 times. No pressure falls exceeding $0.12 \mathrm{in.} / \mathrm{hr}$ were observed during this period. The wind speed assumed for the worst-case scenario is $1.5 \mathrm{~m} / \mathrm{s}$. Stable atmospheric conditions are also assumed for this scenario, but have itttle affect on the estimated concentrations.

With the worst-case atmospheric conditions and the worst-case tank system, the vent flow is estimated to be $0.0099 \mathrm{~m}^{3} / \mathrm{s}$ (21 cfm). (a) Combined with a tributyl phosphate concentration of $197 \mathrm{mg} / \mathrm{m}^{3}$, this vent flow gives a release rate of $2.95 \mathrm{mg} / \mathrm{s}$. Thus, the worst-case release rate is approximately 6 times larger than the release rate estimated in the January 28, 1992, scenario.

Figure 2 shows the tributyl phosphate concentrations predicted by the Gaussian plume model for the worst-case scenario. Plume centerline concentrations exceeding the TLV are predicted to occur to a distance of slightly greater than $4 \mathrm{~m}(14 \mathrm{ft})$. At $10 \mathrm{~m}$ from the vent, the predicted concentration is about $20 \%$ of the TLV, and at $50 \mathrm{~m}(164 \mathrm{ft})$, the predicted concentration is less than $1 \%$ of the TLV.

There may be some question whether a $1.5-\mathrm{m} / \mathrm{s}$ wind speed provides a conservative estimate of the concentrations. Equation (1) clearly shows that concentrations will increase if a lower speed is selected. Validity of the Gaussian plume model depends on the existence of a well-defined wind direction. As the wind speed decreases, the direction becomes poorly defined, and gases will diffuse but their center of mass tends to remain in one place. The

(a) Claybrook 1992. 


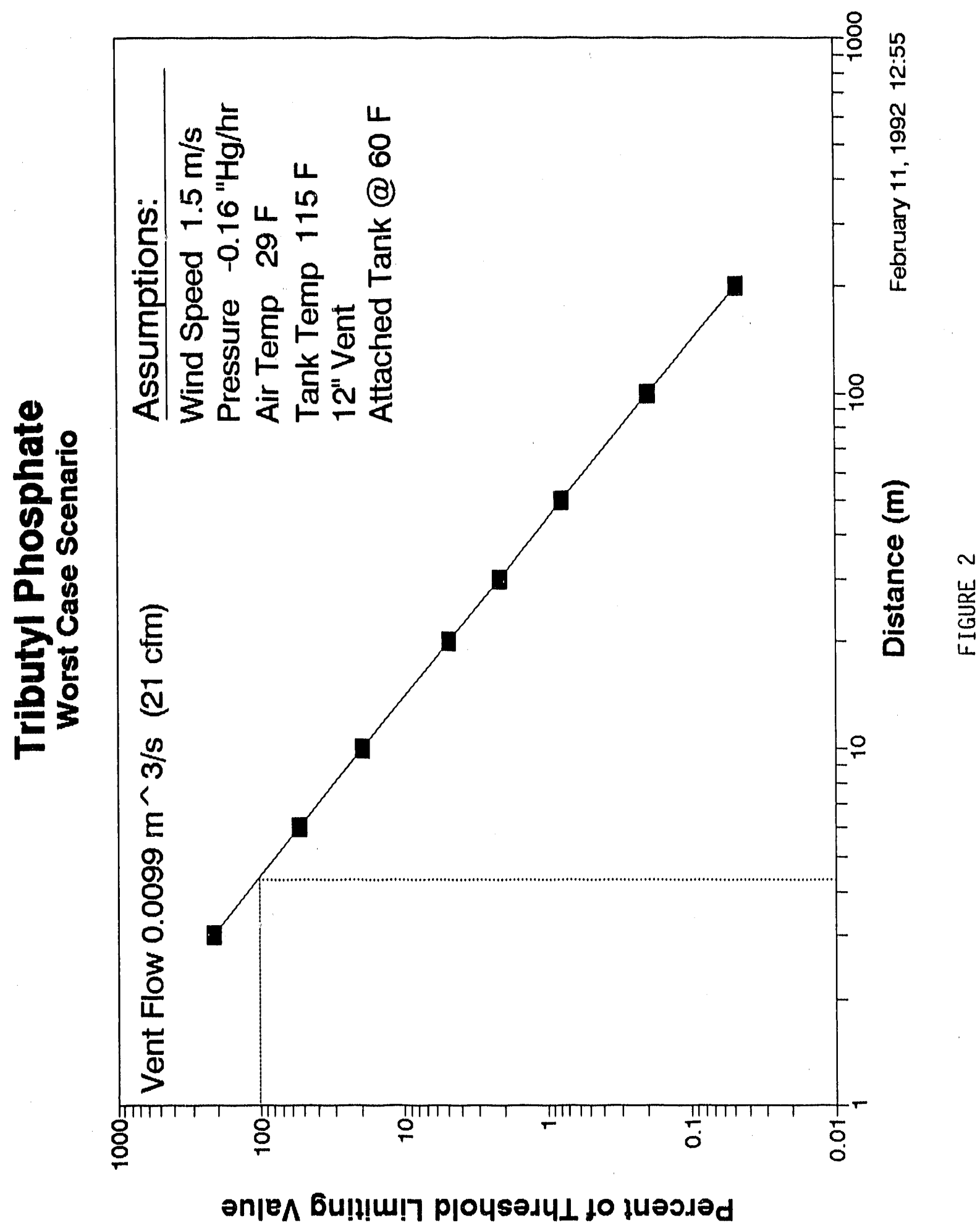


continuous-release puff model was developed to examine concentrations in the limit as the mean wind speed goes to zero. Figure 3 compares the limiting concentrations under calm wind conditions with concentrations in a plume with a $1.5-\mathrm{m} / \mathrm{s}$ wind speed. The indication by Hanna and Chang (1992) that $\sigma_{v}$ has a minimum value that is about an order of magnitude higher than the value used in the puff model strongly suggests that the calm wind concentration estimates in the figure are high. The concentrations in the plume are higher than the calm wind case. Increasing the wind speed would reduce the concentrations predicted by the plume model. Therefore we can conclude that the concentration estimates made by the plume model with a $1.5-\mathrm{m} / \mathrm{s}$ wind speed are adequately conservative.

\section{BOUNDING CASE SCENARIO}

A third scenario was evaluated to determine the potential concentrations that would result if the supply of air to the tank system were unlimited. The atmospheric conditions for this scenario are the same as for the worst-case scenario. The tank system and tank temperatures are also the same, except that a 42-in. access cover was assumed to be open in the tank attached to the release tank. Under these conditions, the flow through the release vent is $0.073 \mathrm{~m}^{3} / \mathrm{s}(155 \mathrm{cfm})$, (a) and the release rate is $14.3 \mathrm{mg} / \mathrm{s}$.

The bounding case release rate is approximately 5 times larger than that of the worst-case scenario. Note, however, that this scenario involves more than normal environmental conditions, it also involves opening a large tank access.

Figure 4 shows the concentrations predicted for the bounding case scenario. Near the tank vent, the concentration is well above the TLV. The concentration decreases to the TLV at $12 \mathrm{~m}(40 \mathrm{ft})$ and is 1 ess than $2 \%$ of the TLV at $100 \mathrm{~m}(310 \mathrm{ft})$.
(a)
claybrook 1992. 


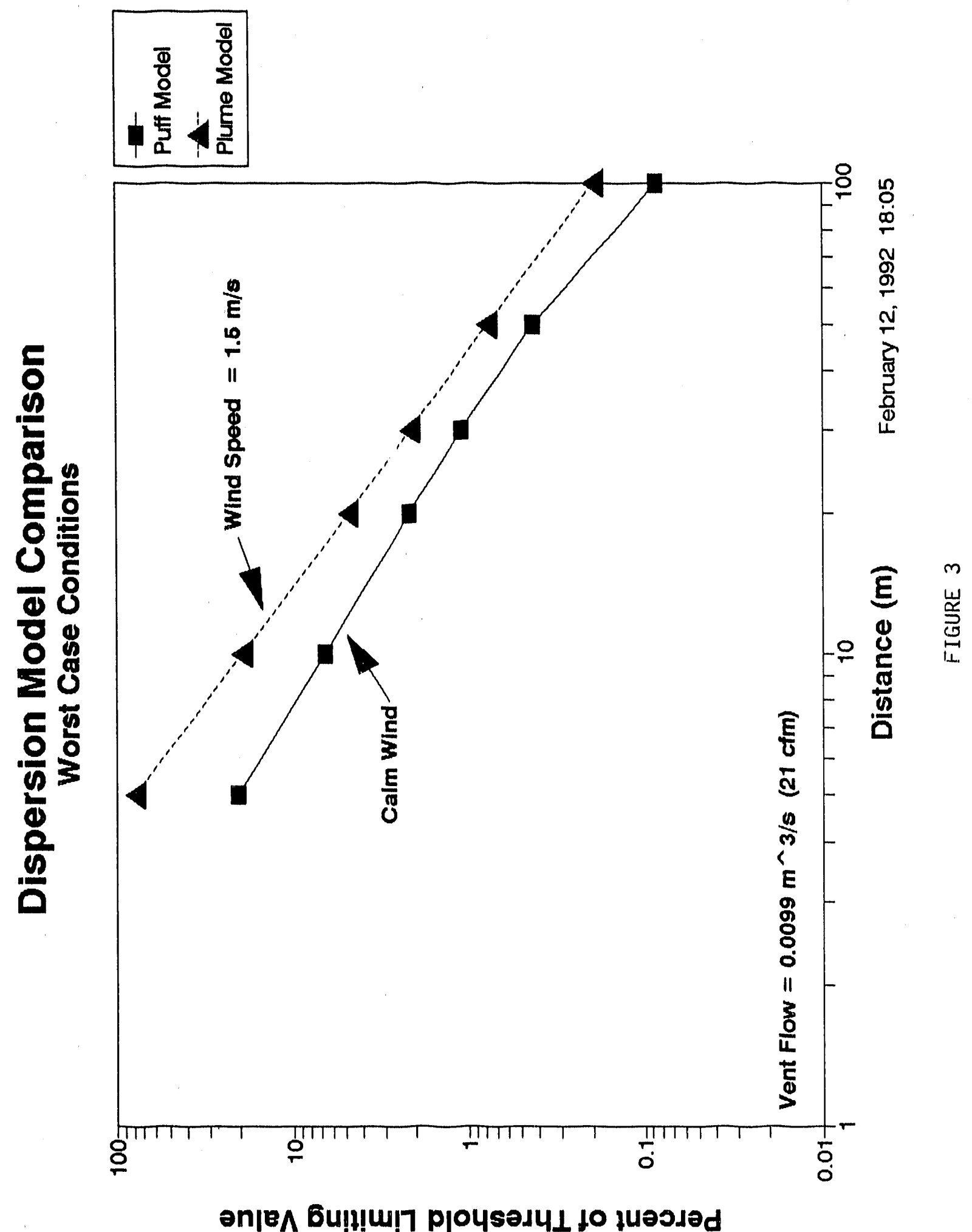




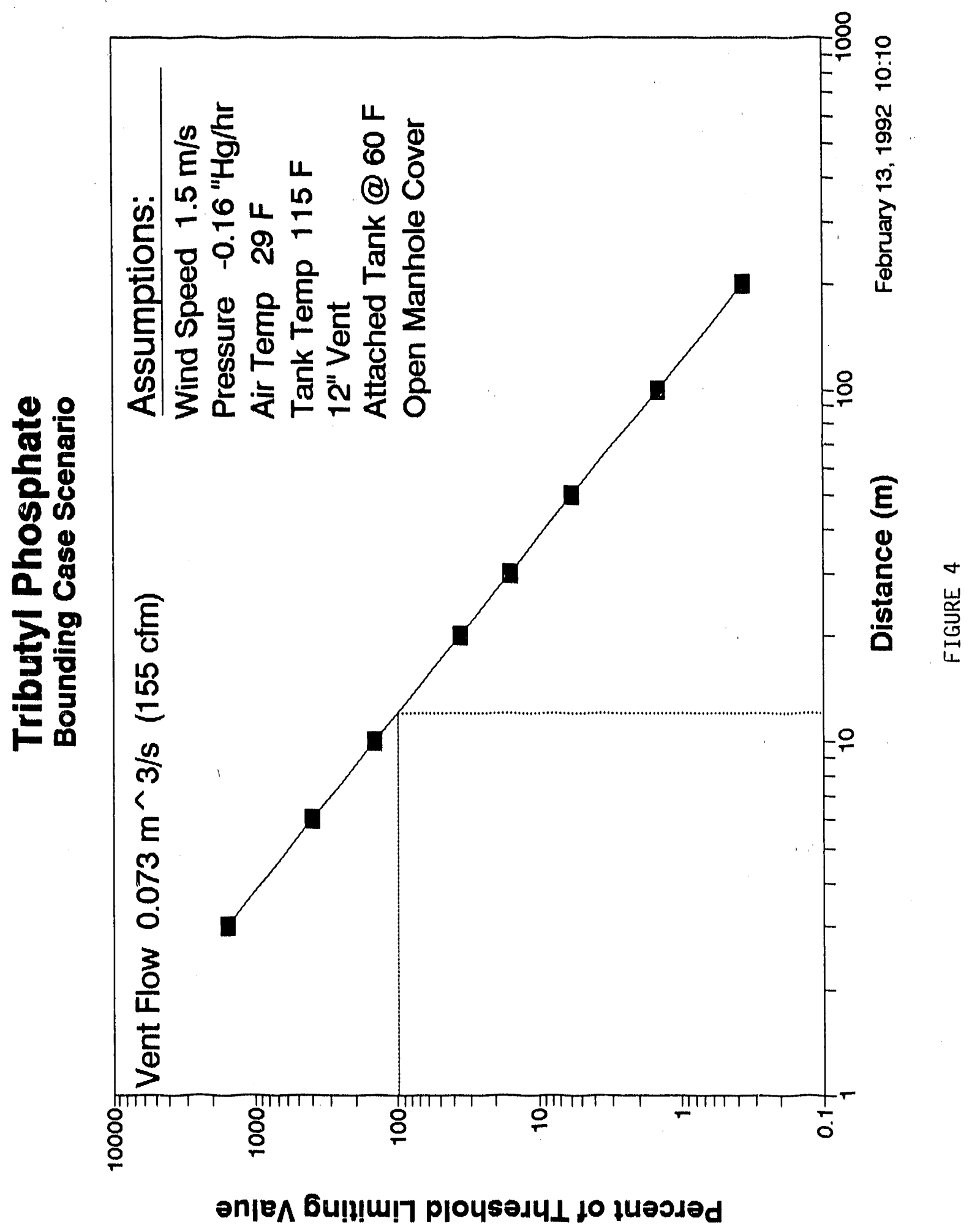




\section{REFERENCES}

ACGIH. 1990. 1990 Threshold Limit Values For Chemical Substances and Physical Agents. American Conference on Governmental Industrial Hygienists, Cincinnati, Ohio.

Gifford, F. A. 1961. "Use of Routine Meteorological Observations for Estimating Atmospheric Dispersion." Nucl. Saf. 2(4):47-57.

Gifford, F. A. 1976. "Turbulent diffusion-typing schemes: a review." Nuc. Safety. $17(1): 68-86$.

Gryning, S. E., A. A. M. Holtslag, J. S. Irwin and B. Sivertsen. 1987. "Applied dispersion modelling based on meteorological scaling parameters." Atmospheric Environment 21:79-89.

Hanna, S. R., and J. C. Chang. 1992. "Boundary-Layer Parameterizations for Applied Dispersion Modeling over Urban Areas." Boundary-Layer Meteorol. $58(3): 229-259$.

Hanna, S. R., G. A. Briggs, J. Deardorff, B. A. Egan, F. A. Gifford and F. Pasqui11. 1977. "AMS workshop on stability classification schemes and sigma curves -- summary of recommendations." Bull. Am. Meteorol. Soc. 58:1305-1309.

Hanna, S. R., G. A. Briggs and R. P. Hosker. 1982. Handbook on Atmospheric Diffusion. DOE/TIC-11223, U.S. Department of Energy, Washington, D.C.

Horst, T. W. and C. E. Elderkin. 1970. "Turbulerice Studies in the Atmospheric Boundary Layer." in Pacific Northwest Laboratory Annual Report for 1969 to the USAEC Division of Blology and Medicine Volume II: Physical Sciences Part 1. Atmospheric Sciences. BNWL-1307, Pacific Northwest Laboratory, Richland, Washington, pp. 63-41.

Irwin, J. S. 1983. "Estimating plume dispersion--a comparison of several sigma schemes." J. Climate Appl. Meteorol. 22:92-114.

NRC. 1982. "Atmospheric Dispersion Models for Potential Accident Consequence Assessments at Nuclear Power Plants." Regulatory Guide 1.145 Rev. 1, U.S. Nuclear Regulatory Commission, Washington, D.C.

Panofsky, H. A. and J. A. Dutton. 1984. Atmospheric Turbulence, J. Wiley \& Sons, New York.

Pasquil1, F. 1961. "The estimation of the dispersion of windborne material." The Meteorological Magazine 90:33-49.

Powe11, D. C. 1974. "Dependence of Site Evaluation of Roughness Length and Displacement Length on Value Chosen for von Karman's Constant", in Pacific Northwest Laboratory Annual Report for 1973 to the USAEC Division of Biomedical and Environmental Research Part 3 Atmospheric Sciences. BNWL-1850 PT3, Pacific Northwest Laboratory, Richland, Washington, pp. 30-32. 
Ramsdel1, J. V., and W. T. Hinds. 1971. "Concentration Fluctuations and Peak-To-Mean Concentration Ratios in Plumes from a Continuous Point Source." Atmospheric Environment. 5(7):483-495.

Randerson, D. 1979. "Review panel on sigma computations." Bull. Am. Meteorol. Soc. 60:682-683.

Stone, W. A., J. M. Thorp, 0. P. Gifford, and D. J. Hoitink. 1983. Ci imatological Summary for the Hanford Area. PNL-4622, Pacific Northwest Laboratory, Ricliland, Washington.

Wei1, J. C. 1985. "Updating applied diffusion models." J. Climate Appl. Meteorol. $24: 1111-1130$. 
No. of

Copies

\section{OFFSITE}

12 DOE/Office of Scientific and Technical Information

\section{ONSITE}

2 DOE Richland Field Office

R. E. Gerton

A. D. Toth

Hanford Environmental Health Eoundation

L. J. Mass

Kaiser Engineers Hanford

D. S. Palmer

7 Westinghouse Hanford Company

H. D. Harmon

M. E. Hevland

J. D. Hopkins

J. R. Kasper

M. A. Payne

R. S. Popielarczyk

R. E. Raymond
No. of

Copies

24 Pacific Northwest Laboratory

R. H. Gray

R. E. Jaquish (5)

J. V. Ramsde11, Jr. (10)

J. T. A. Roberts

Publishing Coordination

Technical Report Files (5)

Routing

R. M. Ecker

J. W. Falco

M. J. Graham

R. L. Skaggs

P. C. Hays (1 ast) 

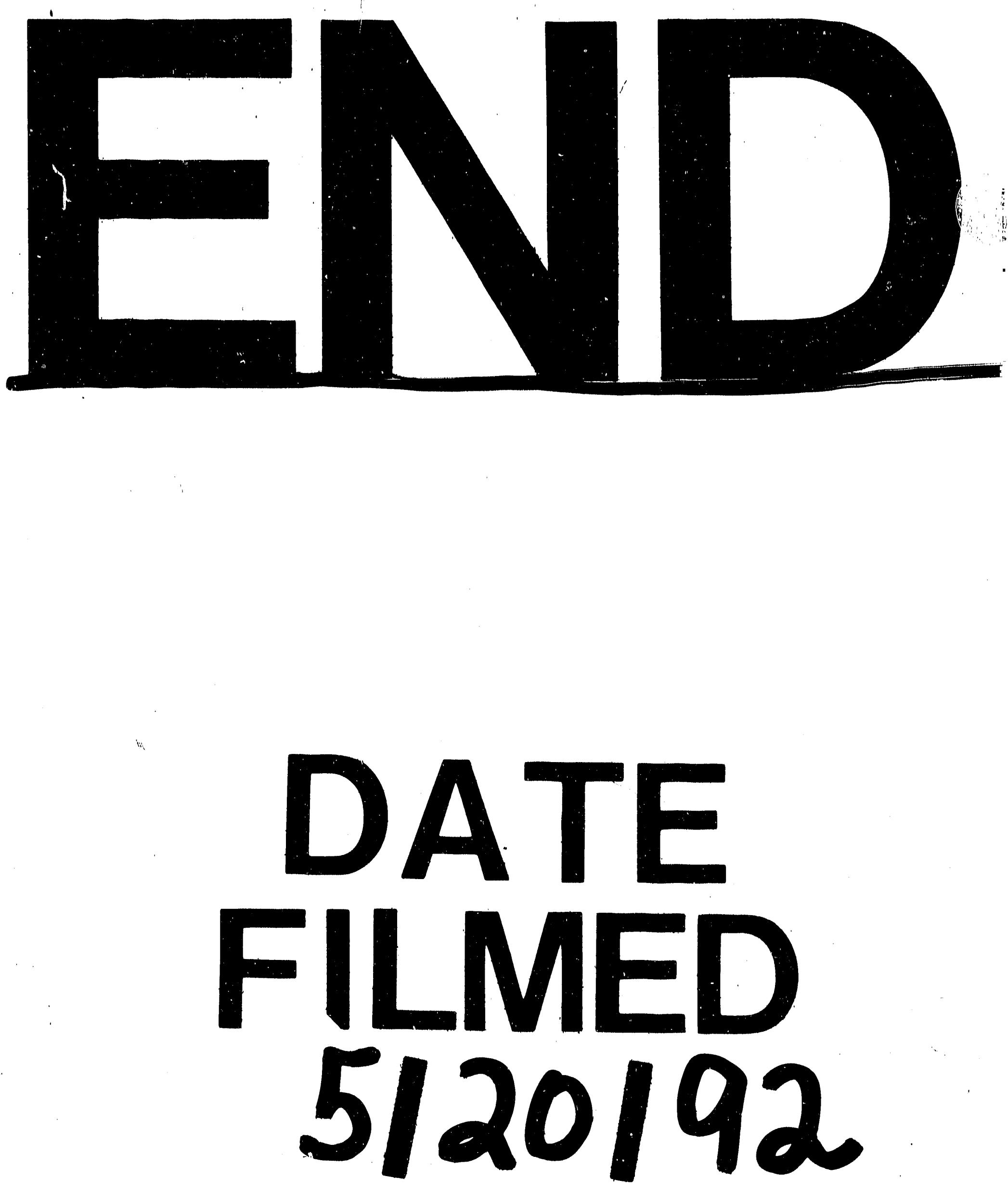